\title{
Studies on Ostertagia spp. from Greenlandic Sheep: Arrested Development and Worm Length
}

\author{
By D. E Jacobs and C. H. Rose \\ State Veterinarian, Qaqortoq, Greenland and \\ the Department of Veterinary Pathology, The Royal Veterinary College, University of London.
}

\begin{abstract}
Jacobs, D. E. and C. H. Rose: Studies on Ostertagia spp. from Greenlandic sheep: arrested development and worm length. Acta vet. scand. 1990, 31, 333-337. - Studies were conducted to investigate earlier observations that lambs slaughtered in Greenland in late September/early October have relatively few arrested larvae in the abomasal mucosa and that the adult Ostertagia from such lambs are abnormally large. Post mortem examination of naturally infected ewes in mid-winter demonstrated that a significant proportion of their Ostertagia population was hypobiotic at this time of year, while an experimental study showed that considerable numbers of larvae of Greenlandic origin became arrested following cold conditioning for 10 weeks. A comparison of adult Ostertagia of Greenlandic and Britain origins from lambs experimentally infected with larvae cultured under identical conditions demonstrated that the "giant" size of the arctic worms was attributed mainly to environmental rather than genetic influences.
\end{abstract}

nematode; morphology; hypobiosis.

\section{Introduction}

As well as providing data on the prevalence of gastrointestinal nematodes, a post mortem study of fat lambs slaughtered at Narssaq, southern Greenland in 1980 produced two noteworthy observations. Firstly, relatively few Ostertagia larvae were recovered from abomasal mucosae. Secondly, the adult Ostertagia spp. were remarkable for their large size, the length of the majority of the worms greatly exceeding the upper limit quoted in standard textbooks (Rose et al. 1984). Studies were therefore initiated to answer two questions:

1. Has the Greenlandic strain of Ostertagia lost the ability to overwinter by undergoing arrested development?

2. Is the size of the Greenlandic abomasal worms collected in 1980 indicative of a locally occurring "giant" strain of Ostertagia?

\section{Materials and methods}

Arrested larval study

Five ewe lambs born in May 1984 that had grazed on open rangeland throughout the summer with the Upernaviarssuk Agricultural Research Station flock and which had never received anthelmintic treatment were slaughtered in January 1985 so that the composition of their abomasal worm populations could be studied.

\section{Strain comparison study}

The objective of this study was to compare the size of Greenlandic and British worms that had developed under precisely similar conditions. To achieve this, Ostertagia spp. larvae were cultured from the faeces of naturally infected Greenlandic sheep in October and November 1984. After transportation to the United Kingdom, a worm-free 
donor lamb was given 7,000 of these larvae by mouth in February 1985 while another was similarly infected with 7,000 larvae of a British strain of $O$. circumcincta supplied by Dr R. J. Thomas of Newcastle University. From this point, material from each donor was handled separately but treated similarly and simultaneously. The larvae harvested from each donor-lamb were stored at $4^{\circ} \mathrm{C}$ until June 1985 when 2 further worm-free lambs were infected with 10,000 larvae of Greenlandic origin while each of a matching pair of lambs received 10,000 donor-derived British larvae. The donor and recipient lambs were slaughtered 49 and 27 days post infection, respectively, so that the abomasal worms could be counted. Twenty male and 20 female worms were randomly selected from each animal for further study.

\section{Parasitology}

Larvae were cultured by mixing faeces with sterilised spaghnum moss or peat and incubated at $18-20^{\circ} \mathrm{C}$ for at least 10 days. They were harvested with a Baermann funnel and washed at least 5 times before storage in tap water at $4^{\circ} \mathrm{C}$. At post mortem, abomasal contents were washed over a 150 $\mu \mathrm{m}$ sieve and the mucosa subjected to acidpepsin digest before being washed over a 38 $\mu \mathrm{m}$ sieve. Adult worms were measured with the aid of a camera lucida.

Table 1. Abomasal worm-counts of five 9-month old Greenlandic ewes.

\begin{tabular}{lrrrl}
\hline Ewe no. & \multicolumn{2}{c}{ Numbers of Osterlagia } & $\begin{array}{c}\text { Percent } \\
\text { arrested }\end{array}$ & $\begin{array}{c}\text { Species } \\
\text { represented }\end{array}$ \\
\cline { 2 - 3 } & adult & larvae & & \\
\hline 1 & 850 & 2140 & 71.6 & Oc \\
2 & 1800 & 740 & 29.1 & Oc \\
3 & 2950 & 4740 & 61.6 & Oc; Ot \\
4 & 0 & 2150 & 100.0 & - \\
5 & 450 & 210 & 31.8 & Oc; Ot \\
\hline
\end{tabular}

Oc-Ostertagia circumcincta

Ot - Ostertagia trifurcata

\section{Results}

\section{Arrested larval study}

The total abomasal worm counts of the 5 ewes ranged from 660 to 7690 (mean 3204) of which between 29.1 and $100 \%$ were larvae (Table 1). The mean body-length of the adult Ostertagia ranged from $12.6-13.1 \mathrm{~mm}$ for the females and $8.7-9.7 \mathrm{~mm}$ for the males (Table 2).

Table 2. Body lengths $(\mathrm{mm})$ of adult Ostertagia from four 9-month old Greenlandic ewes.

\begin{tabular}{lcclcc}
\hline \multirow{2}{*}{ Ewe no. } & \multicolumn{2}{c}{ Female } & & \multicolumn{2}{c}{ Male } \\
\cline { 2 - 3 } \cline { 5 - 6 } & mean & range & & mean & range \\
\hline 1 & 12.6 & $11.8-13.6$ & & 8.7 & $7.9-9.7$ \\
2 & 13.1 & $11.8-15.2$ & & 9.4 & $8.1-10.2$ \\
3 & 12.6 & $11.7-13.6$ & & 9.4 & $8.4-10.3$ \\
4 & 12.9 & $12.2-13.5$ & & 9.7 & $9.2-10.1$ \\
\hline
\end{tabular}

\section{Strain comparison study}

The first passage yielded 346 and 999 adult Ostertagia from lambs infected with the Greenlandic and British worms, respectively. The mean body-lengths were 13.3 and $13.0 \mathrm{~mm}$ respectively, for the female worms and 9.2 and $9.0 \mathrm{~mm}$ for the males. Results for the second passage are displayed in Table 3.

\section{Discussion}

Evidence so far accumulated suggests that the abomasal nematode population of Greenlandic sheep consists entirely of the Teladorsagia species complex, the predominant form being Ostertagia circumcincta with small numbers of the $O$. trifurcata and Teladorsagia davtiani types also present. The data presented in table 1 are consistent with this view. The designation "Ostertagia" has therefore been adopted throughout this paper to describe abomasal worms of Greenlandic origin. 
Table 3. Comparison of worms of Greenlandic and British origin in lambs experimentally infected with 10,000 larvae.

\begin{tabular}{|c|c|c|c|c|}
\hline \multirow{2}{*}{$\begin{array}{l}\text { Origin of larvae } \\
\text { Lamb no. }\end{array}$} & \multicolumn{2}{|c|}{ Greenland } & \multicolumn{2}{|c|}{ Britain } \\
\hline & 1 & 2 & 3 & 4 \\
\hline \multicolumn{5}{|l|}{ Worm-counts: } \\
\hline Ostertagia adults & 2153 & 400 & 2331 & 4123 \\
\hline larvae & 1773 & 560 & 33 & 0 \\
\hline Percent arrested & 45.2 & 71.4 & 1.4 & 0 \\
\hline \multicolumn{5}{|c|}{ Worm-lengths $(\mathrm{mm})$ : } \\
\hline Adult females & $12.1^{\mathrm{ab}}$ & 11.5 & $11.2^{\mathrm{b}}$ & $11.1^{\mathrm{a}}$ \\
\hline Adult males & $8.8^{c}$ & 8.7 & 8.5 & $8.4^{\mathrm{c}}$ \\
\hline
\end{tabular}

Hypobiosis, or arrested development, is an important seasonal mechanism by which Ostertagia populations survive periods when the external environmental may be inimical to preparasitic development (Michel 1974). Yet earlier studies had suggested that relatively few arrested Ostertagia larvae are present in Greenlandic lambs at the time that they are brought in from the open rangeland for slaughter in late September or early October (Rose et al. 1984). Only $4 \%$ of the abomasal worm burden of 11 sheep examined in September 1980 were resident in the mucosa, while the corresponding figure for 9 sheep in October 1980 was $31.5 \%$. In another study, 23 tracer lambs were grazed on rangeland for 6 weeks before slaughter in October 1985 (Rose \& Jacobs 1990). In this case, $19.8 \%$ of the abomasal worm population was juvenile, with no larvae being found in 12 of 19 infected lambs.

In the present study, the 5 ewes had grazed with the flock on open rangeland during the whole summer. After the autumn gathering, they were stabled at night but allowed access to hillside grazing close to the farm buildings during the day. There was no exposure to infection during the weeks immediately be- fore slaughter, however, as the ground was frozen or snow-covered. The larvae recorded in Table 1, which comprised $62.3 \%$ of the total worm population, must therefore have been hypobiotic. The proportion of such larvae in individual ewes varied from 29.1 to $100 \%$ providing evidence that larvae ingested between October and December in Greenland do have an enhanced propensity to become arrested in their development. If the assumption is made that these larvae would have been capable of resuming their development at a later date, then these data provide evidence that Ostertagia does overwinter by hypobiosis in Greenland. This conclusion conforms with earlier epidemiological observations (Rose et al. 1984).

Further confirmation of the capability of the Greenlandic Ostertagia to become hypobiotic was provided by the experimental infection conducted in Britain. After 10 weeks cold conditioning at $4^{\circ} \mathrm{C}, 45.2$ and $71.4 \%$ of the established worms were arrested, respectively, in the 2 lambs (Table 3). This contrasts with corresponding figures of 1.4 and $0 \%$ for the British larvae. This comparison is, however, of little significance as the latter was a laboratory-adapted strain. 
No sheep have been introduced into Greenland since 1915 and so the current Ostertagia population has been geographically isolated for over 70 years. It is conceivable therefore that in adapting to the harsh climate and local management practices, it may have developed unique genetic characteristics. It was against this background that the strain comparison study was initiated. However, when Greenlandic Ostertagia were cultured in parallel with a British strain under identical conditions, the body lengths of each group were broadly similar. While worms from 1 of the 2 lambs infected with Greenlandic larvae were significantly larger than the corresponding British worms (Table 3), this difference was slight and all specimens fell within the accepted range of normality. It must therefore be concluded that the "giant" size of the worms collected in 1980 was mostly the product of environment rather than heredity.

Hong \& Timms (1986) found that the body lengths of a British strain of $O$. circumcincta recovered from experimentally infected parasite-naive lambs were distinctly longer (maximum approximately $13 \mathrm{~mm}$ for female worms) than those from similarly infected immunised lambs (approx. $9 \mathrm{~mm}$ ). A study with tracer lambs (Rose \& Jacobs 1990) showed that many animals grazing the open rangeland might be expected to be exposed to only low levels of challenge during the summer. It is possible therefore that immunity may be slow to develop and, consequently, may be less of a limiting factor to worm growth than is the case in, for example, Europe. This effect would have been particularly pronounced in 1980 when the summer grazing period was particularly dry. The lengths of the Ostertagia recovered from the naturally infected ewes slaughtered in the present study were intermediate in size between those from fat lambs in the
1980 study and those from the experimental infection. This observation is compatible with the above explanation for body-length variation as these sheep had been exposed to infection for a longer period than the autumn-slaughtered fat lambs.

\section{Conclusion}

Evidence from this and earlier studies suggests that Ostertagia does overwinter in Greenlandic sheep by undergoing hypobiosis but that relatively few infective larvae on herbage are primed to become arrested before October. The "giant" size of worms collected from fat lambs in 1980 was mostly attributable to environmental influences and is not a genetically constant feature of this geographically isolated parasitic population.

\section{Acknowledgements}

This work was made possible by a grant from the Wellcome Trust. The cooperation of the staff of the Upernaviarssuk Agricultural Research Station is gratefully acknowledged. Mr. Kai Egede and Prof $P$. Nansen are thanked for their interest and support. The authors are grateful to Dr L. M. Gibbons for expert worm identification.

\section{References}

Hong C, Timms BJ: Variation in size of Ostertagia circumcincta, a nematode parasite of sheep, induced experimentally and during preparation and preservation. Systematic Parasitology 1986, 9, 39-42.

Michel JF: Arrested development of nematodes and some related phenomena. Advanc. Parasitol. 1974, 13, 279-366.

Rose CH, Jacobs DE, Jorgensen RJ, Nansen P: Studies on the helminth parasites of sheep in southern Greenland. Nord. Vet.-med. 1984, 36, 77-87.

Rose CH, Jacobs DE: Epidemiology of sheep nematodes in sub-arctic Greenland: sources of infection on rangeland grazing. Acta vet. scand. 1990, 31, 339-345. 


\section{Sammendrag}

Undersogelser over Ostertagia spp. i fär $i$

Gronland: "arrested development" og orme-

storrelse.

I en tidligere undersøgelse på Grønland fandtes på-

faldende få Ostertagia-larver hos lam slagtet om

efteråret, og de kønsmodne orm var usædvanlig store. Med denne baggrund gennemførtes to nye undersøgelser, én over naturligt inficerede lam, som aflivedes midt på vinteren, og én over lam, som blev eksperimentelt podet med infektive larver, som forud var blevet kulde-konditioneret. I begge tilfælde fandtes et betydeligt antal hypobiotiske larver, hvilket måske tyder på, at grønlandske løbeorm kan overvintre i farrenes slimhinde, som hypobiotiske larver. En sammenlignende undersøgelse over størrelsen af voksne orm, hidrørende fra henholdsvis et grønlandsk og et engelsk podemateriale, viste ingen signifikant forskel, hvorfor den tidligere antagelse af, at grønlandske orm skulle være særlig store, måtte tilbagevises. Det tidligere fund af "store" orm kan eventuelt have en miljømæssig baggrund, men næppe en genetisk.

(Received May 30, 1989; accepted October 18, 1989).

Reprints may be requested from: D. E. Jacobs, The Royal Veterinary College, Boltons Park, Potters Bar, Herts, EN6 INB, U. K. 